\title{
THE RELATIONSHIP BETWEEN FINANCIAL PERFORMANCE AND TOTAL FACTOR PRODUCTIVITY: EVIDENCE FROM THE CZECH AGRICULTURAL SECTOR
}

\section{Ondřej Machek}

University of Economics, Prague

Assistant professor

E-mail: ondrej.machek@vse.cz

\section{-Abstract -}

Agriculture is an important sector of the economy which is often monitored by the government and which is often subject of international disputes. Given the importance of this sector, it is necessary to measure its performance. In this article, we calculated and compared the development of two measures of performance of the agricultural sector of the Czech Republic: the total factor productivity measured by the Fisher index of productivity, and the financial performance measured by three profitability ratios: return on equity, return on assets and return on sales. It is considered that productivity and financial performance do not necessarily move in the same direction. However, we observed a connection between these measures and suggested that this dependence is due to the data interrelatedness. We suggest that total factor productivity, when measured by monetary aggregates such as value added, will be positively correlated to the financial profitability ratios when measured on the basis of the same data. However, for the Czech sector, data are not available due to the transition from the centrally-planned economy to the market economy in 1989 and a turbulent development since that time.

Key Words: Total Factor Productivity; Financial Performance; Agriculture. JEL Classification: Q1, D24 


\section{INTRODUCTION}

Agriculture is an important sector of the economy which is often monitored by the government and which is often subject of international disputes. It has several important roles. The production role is associated with provision of sufficient quantities of affordable products, not only for the needs of food-processing industry, but also as inputs for other industries, such as agrofuels, pharmacy or textile industry. The social and demographic role is related to the generation of employment opportunities and maintaining standards of living especially in the countryside and rural areas. The ecologic and landscape role is associated with the control of pollution and the creation of a cultural landscape. Given the importance of this sector, it is necessary to measure its performance. It is considered that productivity and financial performance do not necessarily move in the same direction. There may be companies which are financially weak but highly productive; on the other hand, there are companies which are financially strong but they perform badly in terms of productivity. However, it is also possible that these measures are somehow interrelated. In this article, we will explore the evidence on the relationship between productivity and financial performance using two measures: the Fisher index of productivity and the financial performance ratios represented by return on assets (ROA), return on equity (ROE) and return on sales (ROS).

\section{TOTAL FACTOR PRODUCTIVITY MEASUREMENT}

Traditionally, productivity is defined as the ratio of output over input. In economic practice, TFP is measured by productivity indexes. Indexes are a common tool to measure price or quantity changes between two periods.

At the aggregate level, total factor productivity is usually measured indirectly. It is the output growth not explicable by changes in the amount of inputs (often referred to as Solow residual). At the individual firm-level, the total factor productivity (TFP) approach takes into account all possible inputs and outputs of the company. In this case, it is necessary to aggregate the set of outputs and inputs. Company-level indexes can be based on distance function or on price aggregation (for detailed discussion, see e.g. Coelli et al.,2005). Among measures based on distance function, we can cite the Malmquist productivity index (Caves, 
Christensen and Diewert,1982). These measures require optimization problem solving (data envelopment analysis) or regression methods (known under the acronyms OLS, COLS, or MOLS) which measure the distance of firms from a real, but unknown frontier. Other TFP measures are based on price aggregation, such as Törnqvist productivity index (Törnqvist,1936) or Fisher productivity index (Fisher,1922). These measures require data about input and output prices, but can be derived directly from empirical data and based on only two observations. In this paper, we will use the Fisher index to measure productivity growth.

Let $\mathbf{x}=\left(x_{1}, x_{2}, \ldots, x_{n}\right)$ denote the vector of input quantities, let $\mathbf{y}=\left(y_{1}, y_{2}, \ldots, y_{m}\right)$ denote the vector of output quantities, $\mathbf{w}=\left(w_{1}, w_{2}, \ldots, w_{n}\right)$ is the vector of input prices and $\mathbf{p}=\left(p_{1}, p_{2}, \ldots, p_{m}\right)$ is the vector of output prices. Let us introduce the Fisher index of productivity (Fisher,1922). It is the geometric average of Laspeyres and Paasche indexes. We can specify the Laspeyres output quantity index $Y_{L}$ or input quantity index $X_{L}$, respectively as

$$
Y_{L}=\frac{\sum_{n=1}^{N} p_{n, t} y_{n, t+1}}{\sum_{n=1}^{N} p_{n, t} y_{n, t}}, X_{L}=\frac{\sum_{m=1}^{M} w_{m, t} x_{m, t+1}}{\sum_{m=1}^{M} w_{m, t} x_{m, t}}
$$

The Paasche output quantity index $Y_{P}$, resp. input quantity index $X_{P}$, can be specified as

$$
Y_{P}=\frac{\sum_{n=1}^{N} p_{n, t+1} y_{n, t+1}}{\sum_{n=1}^{N} p_{n, t+1} y_{n, t}}, X_{P}=\frac{\sum_{m=1}^{M} w_{m, t+1} x_{m, t+1}}{\sum_{m=1}^{M} w_{m, t+1} x_{m, t}}
$$

The Fisher index of productivity is defined as the ratio of geometric averages of Laspeyres and Paasche output and input indexes:

$$
\Pi_{F}=\frac{Y_{F}}{X_{F}}=\frac{\sqrt{Y_{L} Y_{P}}}{\sqrt{X_{L} X_{P}}}
$$


Fisher (and Törnqvist) indexes have several interesting properties, because of which they are classified as exact and superlative indexes. Productivity indexes require price and quantity data on each output and input. The measurement of the data is subject to certain issues; for detailed discussion, see e.g. Machek (2012).

\section{PROPOSED MEASURES OF PRODUCTIVITY AND FINANCIAL PERFORMANCE}

\subsection{Fisher Index of Productivity}

Only one category of output is considered (this approach is similar to the approach used in e.g. Čechura,2012):

- $\quad y$ : total sales of goods, products and services.

Further, five categories of input are considered:

- $x_{1}$ : number of employees (-), which is proxied by total personnel costs divided by the average wages in the industry in the corresponding year (Bašek, 2010);

- $x_{2}$ : energy consumption (toe - tonnes of oil equivalent), which is obtained by the total energy costs divided by the energy consumption in the agricultural sector in the corresponding year;

- $x_{3}$ : other OPEX (in particular, services and depreciation) (CZK), i.e. the difference between OPEX and labor and energy costs; this input reflects services, material consumption and other operational expenses;

- $x_{4}$ : quantity of land used (ha), approximated by the book value of land divided by the average cost of one hectare (Ministry of Agriculture,2011);

- $x_{5}$ : other tangible assets $(\mathrm{CZK})$.

For the TFP calculation, the variables were weighted by revenue shares. The weight of the single output is of 1 . As to the inputs, we adopt a similar approach to OFGEM (2003) and determine the weight of operating expenses (OPEX) as OPEX/revenue. The OPEX part is then divided among $x_{1}, x_{2}$ and $x_{3}$ according to the proportion of labour costs, energy costs and other costs in OPEX. The remaining portion $(1-\mathrm{OPEX} /$ revenue $)$ is attributed to the remaining variables according to their proportion in total tangible assets. 


\subsection{Financial Performance}

Financial performance is often measured by profitability ratios. These ratios are used to evaluate a business's ability to generate earnings compared to its expenses incurred during a period of time. In order to measure the financial performance of the Czech agricultural sector, we employed well-known measures of profitability: return on assets (ROA), return on equity (ROE) and return on sales (ROS).

\subsection{Data}

To collect the data, we used the Albertina database which contains about more than 2,700,000 subjects with registered ID in Czech Republic. We focused on the agricultural companies in the period 2004-2011. Companies containing incomplete data were excluded from the analysis. This way we obtained 10,045 observations in total. For the above-mentioned output and input variables, we aggregated the yearly data and determined their weights and prices.

\section{RESULTS AND DISCUSSION}

\subsection{TFP measured by Fisher index}

The aggregate TFP growth was estimated using input and output quantity indexes. The output quantity index (the aggregate output growth) is denoted by $Y_{F}$, the input quantity index (the aggregate input growth) is denoted by $X_{F}$. The TFP growth is positively affected by the growth of overall output and negatively affected by the growth of inputs. The results are illustrated using fig. 1 and tab. 1 .

Table 1: Development of TFP Measured by the Fisher Index

\begin{tabular}{|r|r|r|r|r|r|r|}
\hline \multicolumn{1}{|c|}{ Year } & \multicolumn{3}{|c|}{ Chain indexes } & \multicolumn{3}{c|}{ Fixed-base indexes } \\
\hline & $Y_{F}$ & $X_{F}$ & $\Delta$ TFP & $Y_{F}$ & $X_{F}$ & $\Delta$ TFP \\
\hline 2004 & - & - & - & 1 & 1 & 1 \\
\hline 2005 & 1.06 & 1.04 & 0.98 & 1.06 & 1.04 & 0.98 \\
\hline 2006 & 1.14 & 1.14 & 1.00 & 1.21 & 1.18 & 0.98 \\
\hline 2007 & 1.19 & 1.23 & 1.04 & 1.44 & 1.46 & 1.01 \\
\hline 2008 & 1.08 & 1.03 & 0.96 & 1.55 & 1.51 & 0.97 \\
\hline
\end{tabular}




\begin{tabular}{|l|l|l|l|l|l|r|}
\hline 2009 & 0.87 & 0.83 & 0.95 & 1.35 & 1.25 & 0.93 \\
\hline 2010 & 0.92 & 1.04 & 1.14 & 1.24 & 1.30 & 1.05 \\
\hline 2011 & 0.95 & 0.98 & 1.04 & 1.17 & 1.28 & 1.10 \\
\hline
\end{tabular}

Figure-1: $\quad$ Development of TFP Measured by the Fisher Index

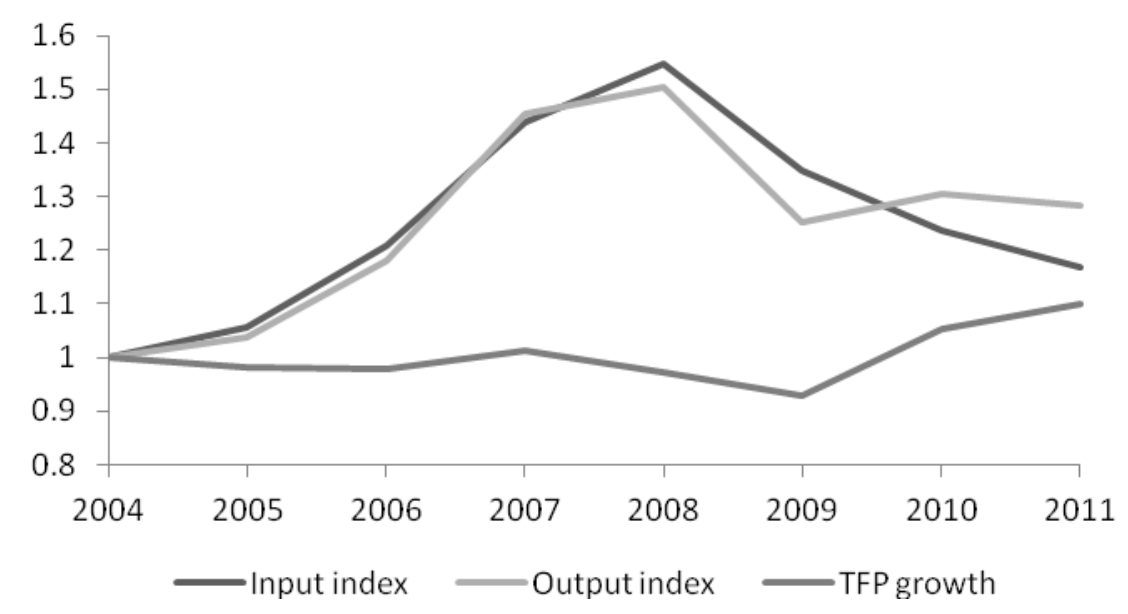

Source: Author.

We can observe a W-shaped development; firstly, in 2004-2006, TFP has decreased by $2 \%$, while in 2007, the productivity has increased and exceeded the basis year (2004). In the following years (2008-2009), the productivity decreased significantly, and finally, since 2010 , it has been increasing again.

\subsection{Development of Profitability Ratios}

Finally, we will analyze the development of the profitability ratios for the Czech agricultural sector. This development is illustrated in Fig. 2. Also in this case, we can see a W-shaped development of the agricultural sector profitability; in 20042006, the profitability has decreased, while in 2007, we observed a sharp increase. In the following years, the profitability decreased, and finally, since 2009, it has been increasing again. 
Figure-2: Development of Profitability Measured by ROE, ROA, and ROS

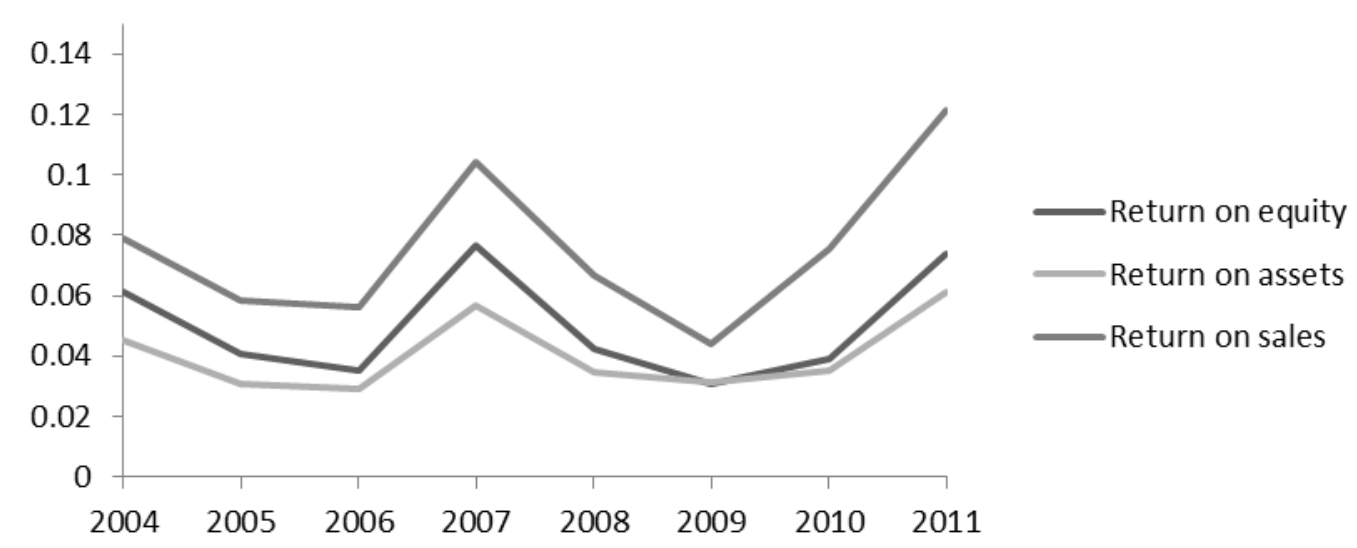

Source: Author.

\subsection{Discussion}

Agricultural sectors are characterized by a relatively high degree of competition, which implies a possibly higher level of productivity than in the regulated or oligopolistic sectors (see e.g. Machek and Hnilica,2012). However, a higher productivity level does not necessarily imply higher productivity growth. In 2004, 2007 and 2011, agricultural enterprises in the Czech Republic attained the best economic results since the EU accession. The main source of income volatility in agriculture is price fluctuation, followed by year-by-year changes in yields (as the result of various weather conditions). However, partially or fully decoupled payments serve as a "financial pillow" increasing the level of the farmers' income and extending the farmers' decision-making possibilities (Špička, Boudný and Janotová,2009). We can also see the negative impact of the 2008-2008 economic recession.

The agricultural sector provides basic inputs for the peoples' livelihood and is highly dependent on changing natural conditions, which would suggest that there is a relatively low sensitivity on the overall economic growth. The price level in agriculture is determined by the foreign price level as well as by the development in the previous year, in particular the weather conditions. On the other hand, the demand for agricultural production is supposed to be relatively steady, unlike the 
demand for other classes of groups. We can suggest that the agricultural TFP growth does not necessarily move in the same direction as the growth of the economy. When comparing the relationship between total factor productivity and financial performance, we can make use of the Figure 3.

Figure-3: Comparing the development of TFP and financial performance

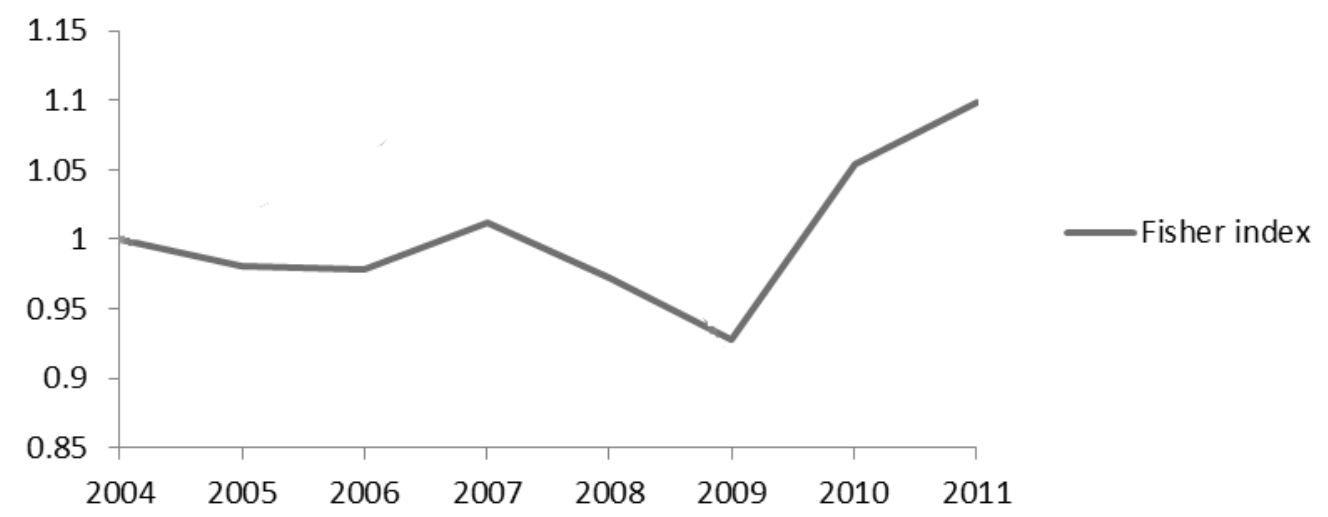

Source: Author.

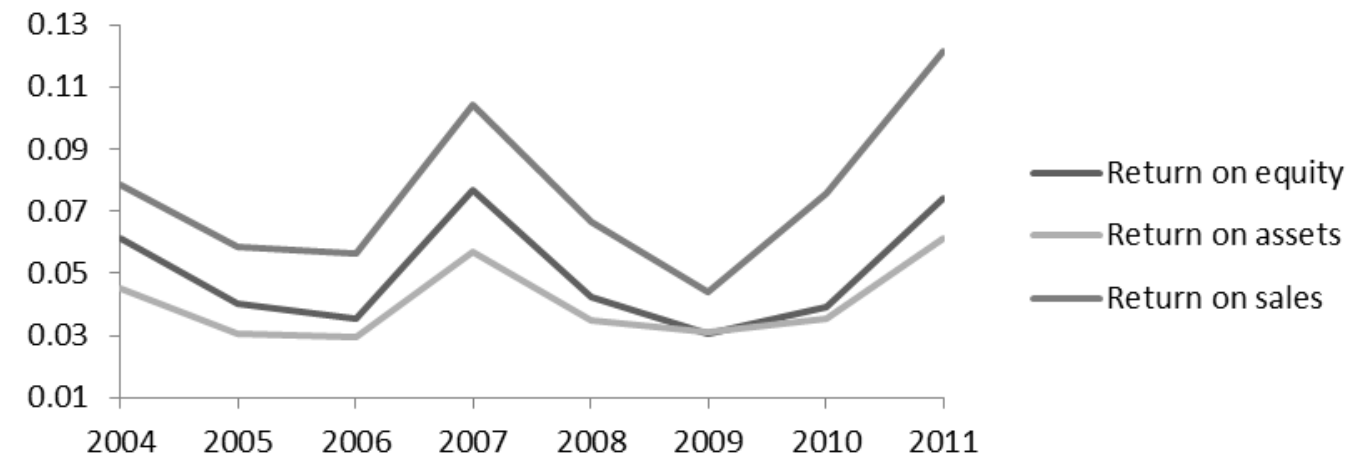

Source: Author.

At first glance, it is evident that TFP, especially when measured by the Fisher's index, is somehow related with the development of the profitability ratios. It can be supported by the following arguments. Let us suppose that profitability increases. It may increase by two ways: either by increasing earnings or by decreasing total assets, equity or sales. If the earnings are increased, then the 
output index will increase; and so will the productivity. If the assets or equity are decreased, then the total input will decrease (since assets are part of the inputs); so, the productivity will increase. We can therefore suppose that TFP, when measured using monetary variables such as value added, gross output etc, is positively related to the profitability and vice versa, if the calculations are based on the same dataset.

\section{CONCLUSION}

Agriculture is a specific sector which, due to its high importance, is often monitored by governments and international agencies. In particular, it is desirable to measure the productive efficiency of this sector. In this article, we calculated and compared the development of two measures of performance: ftotal factor productivity measured by the Fisher index of productivity, and financial performance measured by three profitability ratios: return on equity, return on assets and return on sales. We observed a connection between these measures and suggested that this dependence is due to the data interrelatedness. We suggest that total factor productivity, when measured by monetary aggregates such as value added, will always be positively correlated to the financial profitability ratios, if the calculations are based on the same data. However, our analysis covered only a short time period (2004-2011) since the accession of the Czech Republic to the European Union. A longer period is needed to test the dependence statistically. However, for the Czech sector, data are not available due to the transition from the centrally-planned economy to the market economy in 1989 and a turbulent development since that time. This will be one of the directions of the future research.

\section{ACKNOWLEDGEMENT}

The authors would like to express their gratitude for the financial support of the University of Economics, Prague. The paper is one of the outcomes of the research project VŠE IP300040 "Crucial aspects of the competitiveness of enterprises and national economies in the global economic system". 


\section{BIBLIOGRAPHY}

Bašek, Václav (2010), Czech Agriculture Six Years after EU Accession (in Czech language), Prague: Institute of Agricultural Economics and Information.

Caves, Douglas W, Christensen, Laurits R, Diewert, Erwin W (1982),

"Multilateral Comparisons of Output, Input, and Productivity Using Superlative Index Numbers", Economic Journal, Vol. 2, pp.73-86.

Čechura, Lukáš (2012), “Technical efficiency and total factor productivity in Czech agriculture", Agricultural economics, Vol. 58, No. 4, 2012, pp.147-156.

Coelli, Timothy J, Prasada Rao, Dodla S, O’Donnell, Chris (2005), An introduction to Efficiency and Productivity Analysis, New York: Springer.

Fisher, Irving (1922), The Making of Index Numbers, Boston: Houghton-Mifflin.

Machek, Ondřej (2012), "Data Issues in Total Factor Productivity Benchmarking: A Central European Perspective", The Annals of the University of Oradea. Economic Sciences, Vol. 21, No. 2, 2012, pp.224-230.

Machek, Ondřej, Hnilica, Jiří (2012), "Total Factor Productivity Approach in Competitive and Regulated World", Procedia - Social and Behavioral Sciences, Vol. 57, 2012, pp.223-230.

Ministry of Agriculture (2010), Czech Republic, Final Report on the Agricultural Sector 2011,

http://eagri.cz/public/web/file/191660/Zprava_o_stavu_zemedelstvi_CR_za_rok_ 2011.pdf, [Accessed 3.9.2013].

OFGEM (2003), Productivity Improvements in Distribution Network, London: Cambridge Economic Policy Associates.

Špička, Jindřich, Boudný, Jan, Janotová, Bohdana (2009), “The Role of Subsidies in Managing the Operating Risk of Agricultural Enterprises," Agricultural Economics - Zemedelska ekonomika, Vol. 55, No. 4, pp.169-179. 
INTERNATIONAL JOURNAL OF SOCIAL SCIENCES AND HUMANITY STUDIES

Vol 6, No 2, 2014 ISSN: 1309-8063 (Online)

Törnqvist, Leo (1936), “The Bank of Finland's Consumption Price Index”, Bank of Finland Monthly Bulletin, Vol. 10, 1936, pp.1-8. 